\title{
IV. Extract of a memoir, and experiments on the nutrition of plants
}

\section{Rafn}

To cite this article: M. Rafn (1799) IV. Extract of a memoir, and experiments on the nutrition of plants, Philosophical Magazine Series 1, 5:19, 233-236, DOI: 10.1080/14786449908677145

To link to this article: http://dx.doi.org/10.1080/14786449908677145

曲 Published online: 18 May 2009.

Submit your article to this journal ๘

Џ Article views: 2

Q View related articles ¿ 


\section{[ 233 ]}

IV. Extract of a Memoir, and Experiments on the Nutrition of Plants. By M. RAFN, Afjefor in the Office of Commerce at Copenbagen*.

\section{Tassenfratz confiders carbon as the fubfance which} nourithes vegetablest. Ingenhous, in his work on the nutrition of plants, publifhed in 1797 , endeavours to prove, that if carbon has any influence in this refpect, it can be only in the ftate of carbonic acid, as that acid is abforbed and decompofed + by vegretables; while the ligneous carbon, furnifhed by Nature, produces no effect on the expanfion of plants. Mr. A. Young has endeavoured to demonftrate the fame thing by experiments. M. Rafn, defirous of difcovering the truth amidft thefe contradictory opinions, made, for three years, a feries of experiments, from which he concludes, by the expanfion, fize, and colour of the plants $\mathrm{cm}$ ployed, that carbon, either vegetable or animal, has a decided influence in the nourifhment of vegetables. What is new, and particularly worthy of remark in thefe refearches, is, that, according to M. Rafn, the carbonic acid produces exactly the fame effect as charcoal of wood. The following are the experiments which conducted the author to this refult:-

Having half filled a large box with brick-kiln mbbifh, or pounded tiles, which he covered with a layer of vegetable earth, he placed over the latter a ftratum of carbonate of lime (pounded limeftonc) and alum, and then two or three of vegretable mould, in which he fowed barley. He prefumed that the fulphuric acid of the alum, abandoning the argil to join the lime, with which this acid h.s greater affi-

* Tran?ated form the Darifh, with notes by $C$. Vuuquelin and Brogniats

+ This opinion of $C$. Hafienfratz apprars to be r:ay proba'le; but, as he fays, the caronn muft be hel.t in foluion by tyorogea gas, by watcr, by that faponaccous extrat which feparates from vegetablus when in a At ate of putrefaction, or by any cther licuid.

‡ This decompofition is posivele, but it has not yot been proved by any direet experiment.

VoL. V. 
nity, the carbonic acid gas would be difengaged, which would furnith the means of knowing its influence on the vegetation. Another box was filled merely with mould, a third merely with charcoal, and a fourth with animal carbon. Thele were to be employed in comparative experiments, and barley was fown in them all.

Though the plants which germinated in the firt box were fown in a ftratum of mould about two or three inches in thicknefs, they had no refemblance, either in ftrength or colour, to thofe fown in the fecond box filled with mould alone; but they had, on the other hand, fuch a perfect refemblance to thofe of the third box filled with charcoal, that it would have been difficult to diftinguifh the difference. This refemblance continued feveral weeks, after which they feemed to have not quite the fame vigour as thofe which grew in the charcoal, for which it is not difficult to affign a reafon. The author convinced himfelf that a decompofition had really taken place, becaufe, on examining the firt box in autumn, he found that fulphat of lime had been formed. Thefe experiments feem proper to conduct to a knowledge of the manner in which plants attract the carbonic principle, which all the refearches of the author demonftrate to be necelfary for vigorous vegetation. He propofes to repeat them on a larger feale, and to vary them as much as poffible*. He repeated, feveral times, thofe of M. Humboldt on germination, accelerated by the oxygenated muriatic acid, and always with fuccefs, though with this difference, that this acid did not favour vegetation fo much as that philofopher afferted.

M. Rafn fowed barley in a mixture of mould, fand, and manganefe, in order to fee whether the oxygen gas would

* Thefe experiments would be more condufive had not the author added mould in the boxes into which he put the rubbih. It is will known that mould contains a great quantity of carbon, exactly in the fute which renders it fit for the nutrition of vegetables.

Mr. A. Young, on the other hand, afferts, that plants grow exceedingly ill in charcoal: and this obfervation agrees more with the uthers, and with the reafoning, which induces us to believe that carbon muft be diffolved to enter into combination with the other principles of vegetables. As plants grow exceedingly well in pure water till a certain period, it would appear that they ought to grow equally well in watered charcoal. 
not be difengaged in fuch a manner as to produce fome effect on plants. At firt he obtained no effect; but having watered this box with diluted fulphuric acid, he remarked that the barley vifibly grew fafter in this box than in thofe not watered in the fame manner *.

Of all the mixtures which he tried for fowing, none appeared to him better than that of equal parts of charcoal, mould, and fand, moiftened with water filled with infufion animals, which may be eafily obtained by fteeping flax in the water deftined for that purpofe. He obferves, on this occafion, that, of all the fubftances he tried, flax is that which furnifhes the moft of thefe animalculæe. An incredible multitude of them are found in the water in which women dip their fingers when they are employed in fpinning. The water put into a veffel for that ufe in the morning, is found filled with them in the evening. The author afcribes to thefe fmall animals a much greater influence on vegetation than has hitherto been believed.

Haffenfratz relates, that he could not make plants vegetate well in fimple earths. The author afferts, that he had great fuccefs when he reared them in pure filex, quartzy fand thrice wathed, fine fand from the fea-hhore, \&c. But thefe plants continued ftunted and pale, and their roots were twice as long as the whole of the part above the earth. In charcoal, on the other hand, the parts were large and vigorous; they were of an exceedingly dark colour, and their roots were not a fixth part of the length of the plant itfelf $\uparrow$.

Coal-athes, on which the German and Englifh farmers beftow fuch praife, deftroy the plants if the foil contains an eighth part of that admixture. The leaves become faded, as

* The fu!phuric acid cold does not difengage the oxvetn of the oxyd of manganefe: beides, according to the experiments of Ingentous, this ast alone, in fmall quantity, fictas to have the property of renderitg resetation more active.

+ The firt refults are perfectly fimilar to thofe obtained by C. Haffenfratz. In regard to the fecond, they depend on the purity of the charcoal emplayed, which may contain wood undecompofed, and confequently difpofed to putify, and to yield a liquid which may hold the carbon in folution. 
if fcorched, at the end of from fifteen to twenty days, and the plants themfelves die at the end of four or five weeks.

No feed germinates in oil. A fingle grain of common falk in two hundred grains of water is fufficient to retard the vegetation of plants, and may even kill them if they are watered with that faline liquor *.

Shavings of horn, next to infufion animals, are the moft favourable to vegetation: charcoal holds the third rank.

V. On tbe Affaying of Iron Ores and Iron-Stones by Fufion. By Mr. David Mushet, of the Clyde Iron Works $\dagger$.

$\mathrm{I}_{\mathrm{T}}$

$\mathrm{T}$ will eafily be conceived, from the mode of operation which I have adopted, that, in order to procure accurate refults, the proportion of flux muft be varied according to the mixtures in the iron-ftones or ores; and that no univerfal folvent can be ufed as capable of affaying all ores.

As the gradation of mixtures in the ores is almoft imperceptible, there are, in fact, no fixed limits by which Nature has diftinguifhed the various claffes: we find all the varieties diminining their predominant earth, and affuming, in equal proportions, thofe of each other, thus conftituting the clafs of equalifed mixtures; yet, here, the variety of combination ceafes not, the predominating earth gradually becomes the minor part of the mixture, and that which only held a fecond rank, as to quantity, is now the chief component earth; the permutation goes round, till the earth, which exifted in the moft fparing quantity, now predominates to excefs.

* C. Sylveftore otrained a refule abfolutcly fimilar, by employing marine falt as manure.

+ The prefent is a part of the communication from Mr. Muthet which appeared in our Number for Jily laft, (Vol. IV.p. $17^{\delta}$ ) but by an overfight of the Editor was omitted in its place. It contaibs the table of proportions alluded to in our Numbur for September laft (Vol. IV.p. $3^{\text {fo. })}$ ruquifite for the obtaining from all the various iron-ftones an accurate aflay, and thould have immediately followed Mr. Muthet's arricle given in our July number: 